Article

\title{
o-Carboranylalkoxy-1,3,5-Triazine Derivatives: Synthesis, Characterization, X-ray Structural Studies, and Biological Activity
}

\author{
Guo Fan Jin ${ }^{1,+(\mathbb{D})}$, Hyun Seung Ban ${ }^{2,+(\mathbb{D})}$, Hiroyuki Nakamura ${ }^{3}$ and Jong-Dae Lee ${ }^{4, *(\mathbb{D})}$ \\ 1 School of Pharmacy, Jiangsu University, Zhenjiang 212013, Jiangsu, China; 1000004770@ujs.edu.cn \\ 2 Metabolic Regulation Research Center, Korea Research Institute of Bioscience and Biotechnology, \\ Daejeon 34141, Korea; banhs@kribb.re.kr \\ 3 Laboratory for Chemistry and Life Science, Institute of Innovative Research, Tokyo Institute of Technology, \\ 4259 Nagatsuta-cho, Midori-ku, Yokohama 226-8503, Japan; hiro@res.titech.ac.jp \\ 4 Department of Chemistry, College of Natural Sciences, Chosun University, 309 Pilmundaero, Dong-gu, \\ Gwangju 61452, Korea \\ * Correspondence: jdlee@chosun.ac.kr; Tel./Fax: +82-62-230-6645 \\ + These authors contributed equally to this work.
}

Academic Editor: Piotr Kaszyński

Received: 27 July 2018; Accepted: 29 August 2018; Published: 30 August 2018

\begin{abstract}
Morpholine- and bis(2-methoxyethyl)amine-substituted 1,3,5-triazine derivatives containing an alkoxy-o-carborane in the 6-position of the triazine ring were successfully synthesized. The molecular structures of the methoxy- and ethoxy-o-carboranyl-1,3,5-triazines were established by $\mathrm{X}$-ray crystallography. In vitro studies showed that the methylene bridged morpholine- and bis(2-methoxyethyl)amine-substituted o-carboranyl-1,3,5-triazines accumulated to high levels in B16 melanoma cells and exhibited higher cytotoxicity than p-boronophenylalanine.
\end{abstract}

Keywords: o-Carborane; heterocyclic system; 1,3,5-triazine; morpholine; boron neutron capture therapy

\section{Introduction}

Boron neutron capture therapy (BNCT) is a binary treatment modality for cancer that involves the selective accumulation of chemical agents containing a ${ }^{10} \mathrm{~B}$ isotope in cancer cells and subsequent irradiation with thermal neutrons. Capture of a thermal neutron by the ${ }^{10} \mathrm{~B}$ nucleus initiates a nuclear reaction in which the decay of the excited ${ }^{11} \mathrm{~B}$ nucleus produces a high linear energy transfer $\alpha$-particle and a lithium nucleus. Because of the short trajectories of these heavy particles (5-9 $\mu \mathrm{m}$; approximately one cell diameter), radiation damage is limited to those cells that containing ${ }^{10} \mathrm{~B}$. Thus, side effects typically associated with ionizing radiation can be prevented if ${ }^{10} \mathrm{~B}$ agents can be selectively targeted to tumor cells [1-6].

For BNCT to be successful in the treatment of cancer, the following criteria must be completely addressed: (i) preferential or selective uptake of ${ }^{10} \mathrm{~B}$-containing agent(s) by tumor tissue relative to normal tissue at concentrations high enough to deliver a therapeutic dose of ${ }^{10} \mathrm{~B}$ atoms $\left(20-30 \mu \mathrm{g}{ }^{10} \mathrm{~B}\right.$ per gram of tumor tissue or $10^{9}$ atoms of ${ }^{10} \mathrm{~B}$ per cell); (ii) a tumor/normal tissue differential greater than 1 and preferably in the range of 3-5; and (iii) sufficiently low cytotoxicity and rapid clearance of all ${ }^{10} \mathrm{~B}$ delivery agents from blood and normal tissue [3-12]. The only two BNCT delivery agents currently used in clinical trials are sodium mercaptoundecahydro-closo-dodecaborate $\left(\mathrm{Na}_{2} \mathrm{~B}_{12} \mathrm{H}_{11} \mathrm{SH}\right)$, commonly known as sodium borocaptate (BSH), and the boron-containing amino acid (L)-4-dihydroxy-borylphenylalanine, known as boronophenylalanine or BPA [10]. Neither of these agents adequately fulfills the aforementioned criteria, and for this reason, third-generation agents 
incorporating one or more polyhedral borane anions or carboranes have been investigated. With the development of new synthetic techniques and increased awareness of the biochemical requirements needed for effective boron-containing agents and their modes of delivery, several new boron agents have emerged.

o-Carborane is a stable, lipophilic molecule that resembles benzene in terms of reactivity and bulkiness $[13,14]$. Its remarkable thermal and chemical stabilities make it a unique candidate molecule for use in several specialized applications in the fields of materials science, coordination compounds, and radiopharmaceuticals. The medicinal chemistry of o-carborane, which contains ten boron atoms, gives it a clear advantage for use in BNCT [15]. We previously synthesized 1,2,3,4-tetrahydroisoquinolines [16], 1,3,5-triazines [17-19], and piperidines [20,21] containing the o-carborane unit as potential BNCT agents. However, since carborane cages consist only of $\mathrm{C}-\mathrm{H}$ and B-H units, they have a lipophilic character $[22,23]$. This lipophilicity necessitates the introduction of a second functional group into the o-carboranyl triazine that endows the molecule with water solubility. To meet the requirements for BNCT agents, we designed and synthesized many candidate molecules, increasing their water solubility while maintaining their high boron uptake and low toxicity [20,21]. Among the numerous candidates explored, the 1,3,5-triazine derivatives of the o-carboranyl system $[19,24,25]$ appeared promising in that they showed high boron uptake in cancer cells. Moreover, the water solubility of these molecules was found to improve via the introduction of a second functional group such as an alkylamine moiety [19].

It has been suggested that the incorporation of alkylamine or morpholine functionalities into molecules will increase their water solubilities in biological systems. Recently, we reported morpholineand alkylamine-substituted o-carboranyl-1,3,5-triazine derivatives 1-16 [26]. However, we have confirmed that the purity of compounds 1-16 was not satisfactory when they were prepared in dimethylformamide (DMF) solvent. For this reason, we had difficulty performing spectroscopic and structural analyses and conducting meaningful biological experiments. Thus, we developed a modified procedure using tetrahydrofuran (THF) solvent that significantly improved the purity. In the present study, we report the improved synthesis of mono- or bis(triazinyl)-substituted o-carborane derivatives containing dimorpholine or di(methoxyethyl)amine side groups on nitrogen atoms of the triazine ring. The compounds were characterized by ${ }^{1} \mathrm{H}$ and ${ }^{13} \mathrm{C}$ nuclear magnetic resonance (NMR), and X-ray crystallographic studies, and the cytotoxicity and accumulation of selected molecules were tested in vitro.

\section{Results and Discussion}

\subsection{Synthesis}

The starting materials 4,4'-[6-(alkynyloxy)-1,3,5-triazine-2,4-diyl]dimorpholines and $N^{2}, N^{2}, N^{4}, N^{4}$ tetrakis(2-methoxyethyl)-6-(alkynyloxy)-1,3,5-triazine-2,4-diamines and compounds 1-16 were prepared as reported previously [26]. Briefly, 4,4'-[6-chloro-1,3,5-triazine-2,4-diyl]dimorpholine was treated with an equivalent of prop-2-yn-1-ol with potassium tert-butoxide (t-BuOK) as the base at room temperature in THF to produce 4,4'-[(6-propynyloxy)-1,3,5-triazine-2,4-diyl]dimorpholine. Subsequently, as shown in Scheme 1, the target compounds 1-8 could be easily prepared as described [24,26].

Treatment of alkynyloxy-1,3,5-triazines with decaborane $\left(\mathrm{B}_{10} \mathrm{H}_{14}\right)$ and $N, N$-dimethylaniline as the base in toluene gave the target compounds 5-8 in moderate yields (5 51\%, $649 \%, 740 \%, 840 \%)$. Compounds 5-8 showed the characteristic vibrational absorption bands of the B-H unit in their infrared (IR) spectra at 2588 and $2596 \mathrm{~cm}^{-1}$. Diagnostic signals for compounds 5-7 were observed at $\delta$ 4.45 and 3.89 in the ${ }^{1} \mathrm{H}$ NMR spectra and at $\delta 73.0$ and 72.3 in the ${ }^{13} \mathrm{C}$ NMR spectra of the cage $\mathrm{C}-\mathrm{H}$ unit of the alkynyl group (see Figures S1-S4 for ${ }^{1} \mathrm{H}$ NMR and Figures S5-S8 for ${ }^{13} \mathrm{C}$ NMR, Supplementary Materials). To validate the NMR-based assignments of the final compounds, $\mathrm{X}$-ray structural study of 5 and $\mathbf{6}$ were conducted to confirm their basic structures (Figures 1 and 2, respectively). Crystals 
suitable for X-ray crystallography were obtained from dichloromethane solutions of $\mathbf{5}$ and $\mathbf{6}$ by slow evaporation at ambient temperature; subsequent $X$-ray analysis provided definitive proof of their structures.

A similar synthetic protocol was used for the preparation of 6-(o-carboranylalkoxy)$N^{2}, N^{2}, N^{4}, N^{4}$-tetrakis(2-methoxyethyl)-1,3,5-triazine-2,4-diamines 9-16, as shown in Scheme 2.

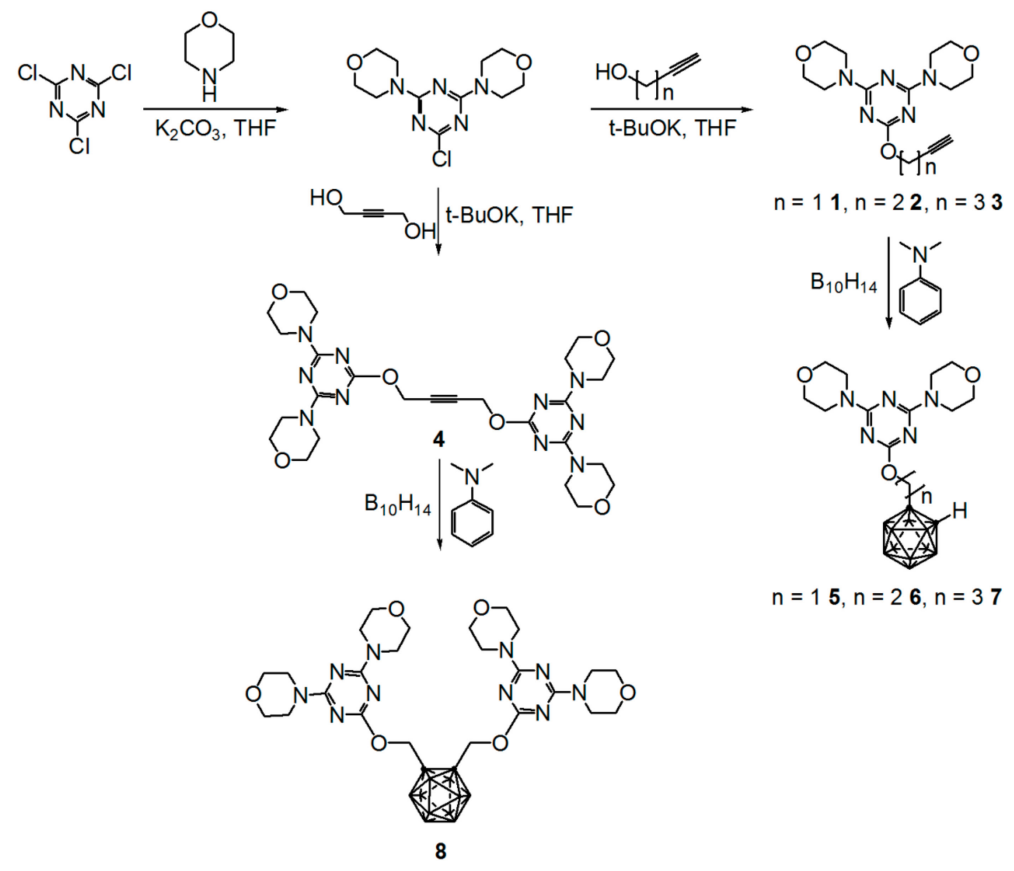

Scheme 1. Preparation of 4,4'-[(6-alkynyloxy)-1,3,5-triazine-2,4-diyl]- and 4,4'-[(6-o-carboranylalkoxy)1,3,5-triazine-2,4-diyl]dimorpholines (1-8).

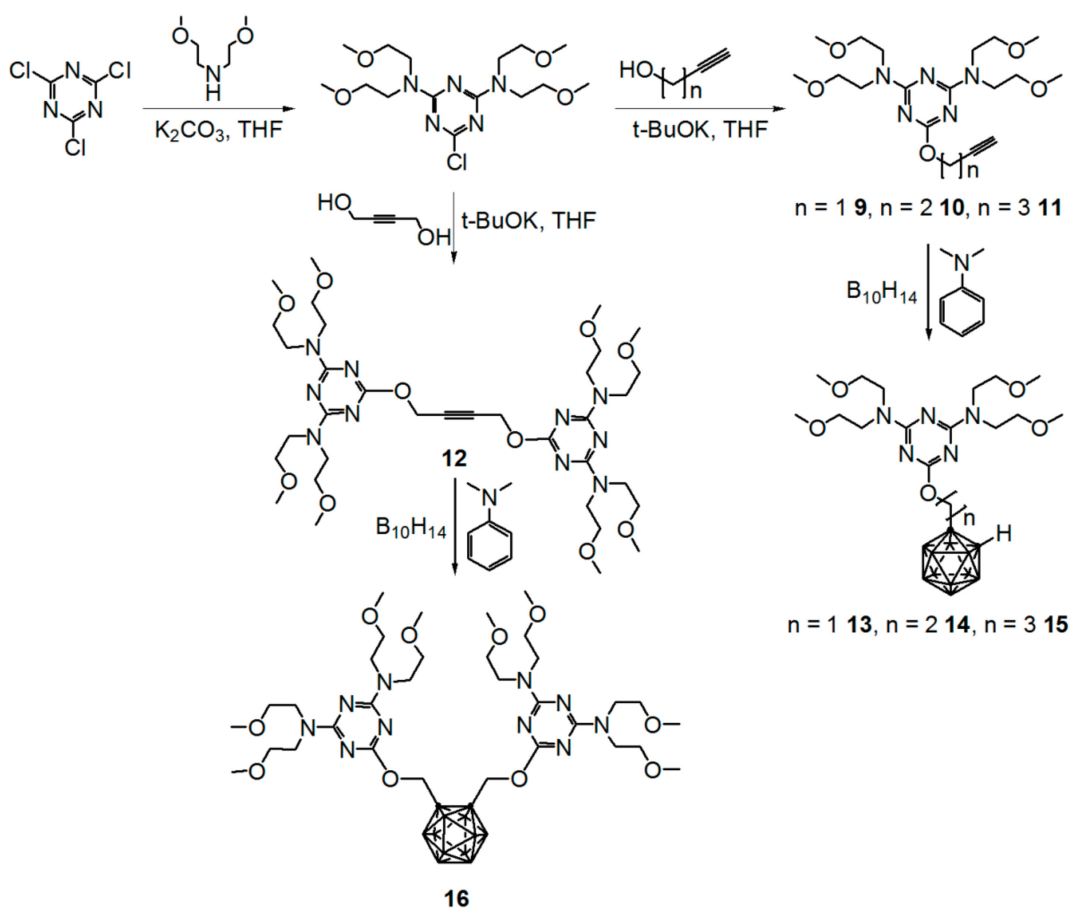

Scheme 2. Preparation of $N^{2}, N^{2}, N^{4}, N^{4}$-tetrakis(2-methoxyethyl)-6-(alkynyloxy)- and (6-ocarboranylmethoxy)- $N^{2}, N^{2}, N^{4}, N^{4}$-tetrakis(2-methoxyethyl)-1,3,5-triazine-2,4-diamines (9-16). 
The addition of decaborane and $N, N$-dimethylaniline to toluene solutions of the 4,4'-[(6-alkynyloxy)-1,3,5-triazine-2,4-diyl]dimorpholines gave the target compounds 13-16 in moderate yields (13 51\%, 14 49\%, 15 40\%, 16 15\%). Compounds 13-16 showed absorption bands near 2587-2596 cm $\mathrm{cm}^{-1}$ in their IR spectra; these bands are characteristic of vibrations of the B-H unit. Diagnostic signals for compounds 13-15 were observed near $\delta 3.63-4.45$ in the ${ }^{1} \mathrm{H}$ NMR spectra and near $\delta 72.3-74.8$ in the ${ }^{13} \mathrm{C}$ NMR spectra of the cage C-H unit of the alkynyl group (see Figures S9-S12 for ${ }^{1} \mathrm{H}$ NMR and Figures S13-S16 for ${ }^{13} \mathrm{C}$ NMR, Supplementary Materials). The ${ }^{1} \mathrm{H}$ NMR spectra of compounds 13-16 showed a broad signal arising from the B-H unit of the o-carborane moiety from $\delta$ 0.5 to 3.4 .

\subsection{X-ray Structural Studies on $\mathbf{5}$ and $\mathbf{6}$}

The X-ray structures of compounds 5 and 6 were consistent with those proposed on the basis of the NMR assignments. Selected crystallographic data and selected bond lengths and angles of 5 and 6 are summarized in Tables 1 and 2, respectively. Detailed information on the structural determinations and structural features of compounds 5 and $\mathbf{6}$ are provided in the Supplementary Materials and Appendix A. The ORTEP diagram in Figure 1 depicts the molecular structure of 5, confirming it as 4,4'-[6-(o-carboranylmethoxy)-1,3,5-triazine-2,4-diyl]dimorpholine. As expected, the morpholine rings adopt chair conformation. The $\mathrm{C}-\mathrm{N}$ distances in the $\mathrm{C}_{3} \mathrm{~N}_{3}$ ring are in the typical range for double bonds (average $1.33 \AA$ ). This value is similar to the mean $\mathrm{C}-\mathrm{N}$ bond distances reported for other (1,3,5-triazine-2,4-diyl)dimorpholine derivatives, e.g., $1.34 \AA$ for 2-chloro-4,6-dimorpholino-1,3,5-triazine [27] and $1.34 \AA$ for 4,6-dimorpholino-N-(2,4,4-trimethylpentan-2-yl)-1,3,5-triazin-2-amine [28]. The C1-C2 bond length of the carborane unit is within the typical range [1.627(2) $\AA$ ]. This value is similar to the C1-C2 bond lengths of the parent compound [1.629(6) and 1.630(6) $\AA$ ] [29] and is somewhat larger than our previous reported value [1.614(3) $\AA$ ] [30]. The B-C bond lengths range from 1.686(3) to 1.713(3) $\AA$, whereas the $\mathrm{B}-\mathrm{B}$ bond lengths range from 1.762(3) to 1.782(3) A. The torsion angle between the 1,3,5-triazine ring and the ether linkage is $178.9(3)^{\circ}$. The torsion angles of C20-N4-C15-N1 and C24-N5-C16-N3 are 175.0(2) and 179.4(2) ${ }^{\circ}$, respectively. Furthermore, the planes of C17-N4-C20 and C21-N5-C24 are nearly coplanar with the 1,3,5-triazine ring, with dihedral angles of $9.69(3)$ and $13.68(1)^{\circ}$, respectively.

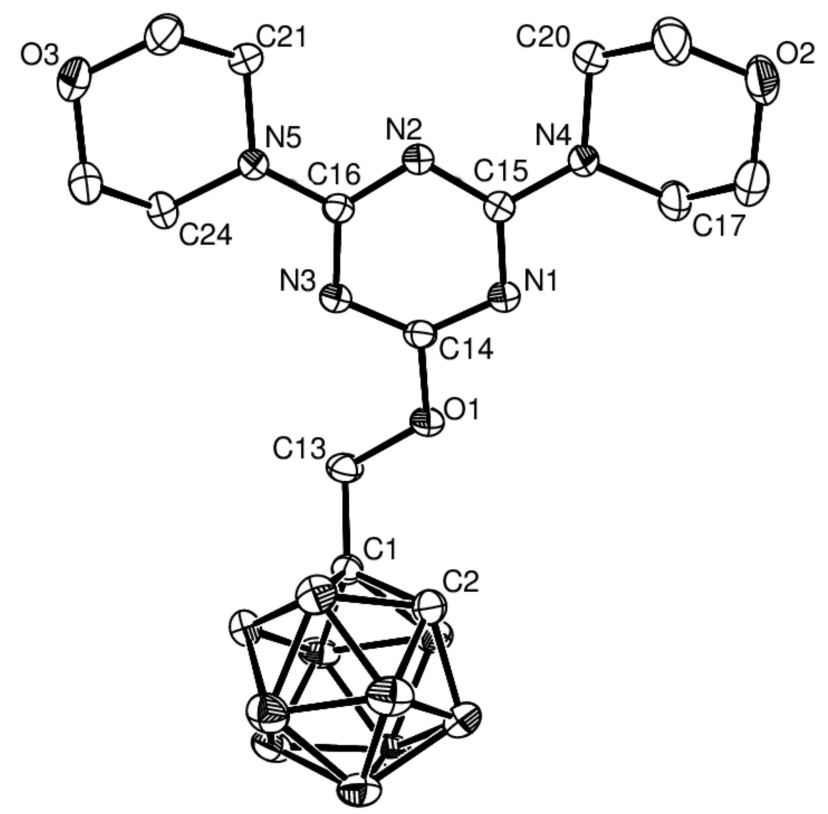

Figure 1. Molecular structure of 5 with thermal ellipsoids drawn at the $30 \%$ level. Hydrogen atoms are omitted for clarity. 
The single-crystal X-ray diffraction study of 6 revealed that it crystallized in the triclinic space group P-1 (Figure 2). The C-N bond lengths in the 1,3,5-triazine ring varied from 1.311(2) to 1.349(2) $\AA$, which are between the bond lengths of a $\mathrm{C}-\mathrm{N}$ single bond $(1.470 \AA)$ and $\mathrm{C}=\mathrm{N}$ double bond

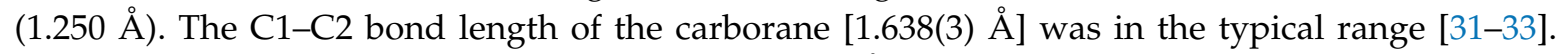
The B-C bond lengths lay between 1.690(3) and 1.730(3) $\AA$, whereas the B-B bond lengths ranged from $1.758(3)$ to $1.793(4) \AA$. The torsion angles of C21-N4-C16-N1 and C22-N5-C17-N3 are -174.1(2) and $179.6(2)^{\circ}$,respectively. Moreover, the torsion angles of C14-O1-C15-N1, C1-C13-C14-O1, C15-O1-C14-C13, and C14-C13-C1-C2 were -175.8(2), 173.4(2), -80.5(2), and 167.8(2) ${ }^{\circ}$, respectively. The planes of C18-N4-C21 and C22-N5-C25 were nearly coplanar with the 1,3,5-triazine ring and had dihedral angles of $4.50(4)$ and $7.01(2)^{\circ}$, respectively.

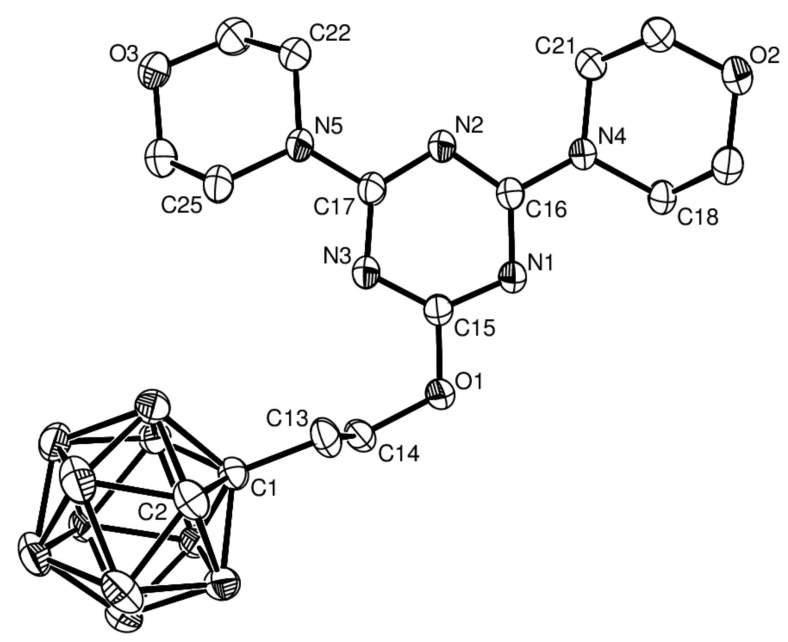

Figure 2. Molecular structure of 6 with thermal ellipsoids drawn at the $30 \%$ level. Hydrogen atoms are omitted for clarity.

Table 1. Crystal data and structure refinement of 5 and 6.

\begin{tabular}{|c|c|c|}
\hline Identification Code & cnu1002 & cnu1001 \\
\hline Empirical formula & $\mathrm{C}_{14} \mathrm{H}_{29} \mathrm{~B}_{1} 0 \mathrm{~N}_{5} \mathrm{O}_{3}$ & $\mathrm{C}_{15} \mathrm{H}_{30} \mathrm{~B}_{10} \mathrm{~N}_{5} \mathrm{O}_{3}$ \\
\hline Formula weight & 423.52 & 436.54 \\
\hline Temperature & 293(2) K & 293(2) K \\
\hline Wavelength & $0.71073 \mathrm{~A}$ & $0.71073 \mathrm{~A}$ \\
\hline Crystal system, space group & Triclinic, $\mathrm{P}-1$ & Triclinic, $\mathrm{P}-1$ \\
\hline Unit cell dimensions & $\begin{array}{c}a=7.03880(10) \AA, \alpha=87.1180(10)^{\circ} \\
b=9.7116(2) \AA, \beta=88.4920(10)^{\circ} \\
c=16.9533(3) \AA, \gamma=74.5480(10)^{\circ}\end{array}$ & $\begin{array}{c}a=9.7505(3) \AA, \alpha=88.224(2)^{\circ} \\
b=11.1591(4) \AA, \beta=74.390(2)^{\circ} \\
c=11.9630(4) \AA, \gamma=67.088(2)^{\circ}\end{array}$ \\
\hline Volume & $1115.49(3) \AA^{-3}$ & $1150.74(7) \AA^{-3}$ \\
\hline $\mathrm{Z}, \mathrm{D}_{\text {calc }}$ & $2,1.261 \mathrm{~g} / \mathrm{cm}^{3}$ & $2,1.260 \mathrm{~g} / \mathrm{cm}^{3}$ \\
\hline$m$ & $0.079 \mathrm{~mm}^{-1}$ & $0.079 \mathrm{~mm}^{-1}$ \\
\hline$F(000)$ & 444 & 458 \\
\hline Crystal size & $0.24 \times 0.20 \times 0.15 \mathrm{~mm}$ & $0.26 \times 0.22 \times 0.19 \mathrm{~mm}$ \\
\hline$\theta$ range for data collection & 1.20 to $28.14^{\circ}$ & 1.77 to $28.34^{\circ}$ \\
\hline Limiting indices & $-9 \leq \mathrm{h} \leq 9,-10 \leq \mathrm{k} \leq 12,-21 \leq 1 \leq 21$ & $-13 \leq \mathrm{h} \leq 13,-14 \leq \mathrm{k} \leq 14,-15 \leq 1 \leq 15$ \\
\hline Reflections collected/unique & $16295 / 5176[\mathrm{R}(\mathrm{int})=0.0292]$ & $31151 / 5711[\bar{R}($ int $)=0.0465]$ \\
\hline Completeness to $\theta=25.96$ & $94.9 \%$ & $99.8 \%$ \\
\hline Refinement method & Full-matrix least-squares on $\mathrm{F}^{2}$ & Full-matrix least-squares on $\mathrm{F}^{2}$ \\
\hline Data/restraints/parameters & $5176 / 0 / 289$ & $5711 / 0 / 299$ \\
\hline Goodness-of-fit on $F^{2}$ & 1.055 & 1.124 \\
\hline Final $R$ indices $[\mathrm{I}>2 \mathrm{~s}(\mathrm{I})]$ & $\mathrm{R} 1=0.0528, \mathrm{wR} 2=0.1335$ & $\mathrm{R} 1=0.0647, \mathrm{wR} 2=0.2064$ \\
\hline $\mathrm{R}$ indices (all data) & $\mathrm{R} 1=0.0829, \mathrm{wR} 2=0.1540$ & $\mathrm{R} 1=0.0840, \mathrm{wR} 2=0.2238$ \\
\hline Extinction coefficient & & $0.011(5)$ \\
\hline Largest diff. peak and hole & 0.205 and $-0.272 \mathrm{e} . \AA^{-3}$ & 0.807 and -0.360 e..$\AA^{-3}$ \\
\hline
\end{tabular}


Table 2. Selected bond lengths $(\AA)$ and angles $\left(^{\circ}\right)$ of 5 and 6 .

\begin{tabular}{cccc}
\hline & & & \\
\hline C1-C2 & $1.627(2)$ & N1-C14 & $1.317(2)$ \\
O1-C14 & $1.358(2)$ & N1-C15 & $1.352(2)$ \\
O1-C13 & $1.429(2)$ & N3-C14 & $1.318(2)$ \\
N4-C15 & $1.348(2)$ & N3-C16 & $1.355(2)$ \\
N5-C16 & $1.350(2)$ & N2-C15 & $1.339(2)$ \\
C1 C13 & $1.520(2)$ & N2-C16 & $1.335(2)$ \\
C14-O1-C13 & $118.8(1)$ & C13-C1-C2 & $119.7(1)$ \\
O1-C13-C1 & $109.4(1)$ & N1-C14-N3 & $129.4(1)$ \\
N1-C14-O1 & $111.7(1)$ & N3-C14-O1 & $118.9(1)$ \\
N2-C15-N1 & $125.4(1)$ & N2-C16-N3 & $125.5(1)$ \\
\hline & & & \\
\hline C1-C2 & $1.638(3)$ & O1-C14 & $1.444(2)$ \\
O1-C15 & $1.351(2)$ & C13-C14 & $1.504(3)$ \\
C1-C13 & $1.531(2)$ & N1-C15 & $1.324(2)$ \\
N1-C16 & $1.349(2)$ & N2-C16 & $1.342(2)$ \\
N2-C17 & $1.336(2)$ & N3-C15 & $1.311(2)$ \\
N3-C17 & $1.347(2)$ & & \\
C15-N3-C17 & $113.03(15)$ & C15-N1-C16 & $112.50(14)$ \\
C17-N2-C16 & $114.04(16)$ & C15-O1-C14 & $116.47(14)$ \\
C13-C1-C2 & $116.26(14)$ & C14-C13-C1 & $112.70(16)$ \\
O1-C14-C13 & $111.28(16)$ & N3-C15-N1 & $128.89(17)$ \\
N3-C15-O1 & $118.03(15)$ & N1-C15-O1 & $113.08(15)$ \\
\hline
\end{tabular}

\subsection{Determination of $I C_{50}$ and Incorporation of Boron into B16 Cells}

B16 mouse melanoma and HeLa human cervical carcinoma cells were treated with compounds 5-8 and 13-16 for 3 days, after which the cell viability was determined by the MTT [3'-(4,5-dimethylthiazol-2-yl)-2,5-diphenyltetrazolium bromide] assay. As can be seen from Table 3, compounds 5-8 and 13-16 showed higher cytotoxicity than BPA, with $\mathrm{IC}_{50}$ (the half maximal inhibitory concentration) values in the range of 13.1-28.6 $\mu \mathrm{M}$. Interestingly, methyleneand ethylene-bridged compounds $(5,6,13$, and 14) showed slightly higher cytotoxicity than the propylene- and 1,2-disubstituted ortho-carboranes $(7,8,15$, and 16) in B16 and HeLa cells. The higher cytotoxicity of compounds 5-8 in B16 cells may be a result of the difference between the natures of the morpholine-substituted compounds 5-8 and the bis(2-methoxyethyl)amine-substituted compounds 13-16. In HeLa cervical carcinoma cells, compounds 5-8 and 13-16 exhibited similar activities, with $\mathrm{IC}_{50}$ values in the range of $15.9-21.5 \mu \mathrm{M}$.

Table 3. Cytotoxicity $\left(\mathrm{IC}_{50}\right)$ of B16 melanoma and HeLa cervical carcinoma cells.

\begin{tabular}{ccc}
\hline \multirow{2}{*}{ Compound } & \multicolumn{2}{c}{${\text { Cytotoxicity } \mathrm{IC}_{\mathbf{5 0}}(\boldsymbol{\mu M})^{a}}^{a}$} \\
\cline { 2 - 3 } & B16 & HeLa \\
\hline $\mathbf{5}$ & $14.6 \pm 0.5$ & $17.4 \pm 2.0$ \\
$\mathbf{7}$ & $13.9 \pm 1.1$ & $15.9 \pm 3.3$ \\
$\mathbf{8}$ & $20.9 \pm 1.8$ & $18.1 \pm 0.7$ \\
$\mathbf{1 3}$ & $18.5 \pm 0.6$ & $20.3 \pm 3.5$ \\
$\mathbf{1 4}$ & $17.0 \pm 1.4$ & $16.4 \pm 1.9$ \\
$\mathbf{1 5}$ & $13.1 \pm 1.2$ & $17.5 \pm 1.4$ \\
$\mathbf{1 6}$ & $27.9 \pm 1.6$ & $21.5 \pm 0.9$ \\
BPA & $28.6 \pm 1.0$ & $20.5 \pm 1.4$ \\
\end{tabular}

${ }^{a}$ B16 melanoma and HeLa cervical cancer cells were incubated for $72 \mathrm{~h}$ in the presence of compounds $5-8$ and 13-16, and then the percentages of viable cells were determined by MTT assay. The drug concentrations required to inhibit cell viability by $50 \%\left(\mathrm{IC}_{50}\right)$ were determined from semi-logarithmic concentration-response plots, and the results represent the means \pm s.d. of triplicate samples. ${ }^{b}$ n.d., not determined. 
We next examined the level of intracellular accumulation of the compounds 5-8 and 13-16 by determining their boron concentrations via inductively coupled plasma atomic emission spectroscopy (ICP-AES). As shown in Figure 3, the intracellular boron uptake of compounds 5-8 and 13-16 was higher than that of BPA in B16 cells. Among the compounds synthesized, methylene-bridged compounds 5 and $\mathbf{1 3}$ showed more than six times higher boron accumulation than BPA. The boron uptake from both morpholine- and bis(2-methoxyethyl)amine-substituted compounds having a higher number of bridge carbon atoms, which included ethylene- and propylene-bridged compounds (i.e., 6, 7, 14, and 15), was lower. However, it should be noted that the accumulated boron concentrations of 1,2-bis[(4,6-disubstituted-1,3,5-triazin-2-yloxy)methyl]-o-carboranes (8 and 16) were lower than those of compounds 5-7 and 13-15 despite the similar boron concentrations of all these compounds; this result is attributed to the differences in the molecular size of these compounds. In addition, the intracellular boron uptake into B16 cells appears to correlate with the cytotoxicity of compounds. The compounds with greater cellular boron uptake had lower $\mathrm{IC}_{50}$ values for cytotoxicity in B16 cells.

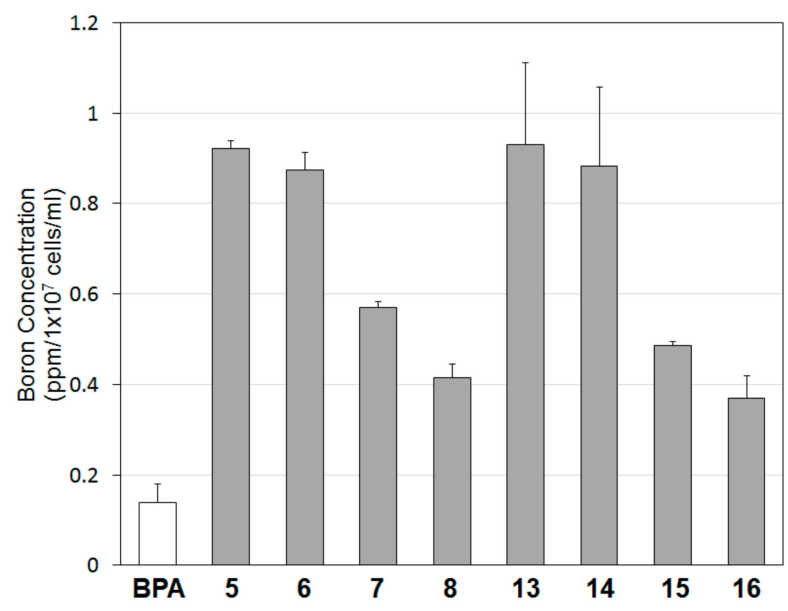

Figure 3. Intracellular boron uptake of compounds 5-8 and 13-16. B16 melanoma cells were incubated for $3 \mathrm{~h}$ in the presence of each boron compounds or BPA $(10 \mu \mathrm{M})$. Then the cells were digested and their boron concentrations were determined by ICP-AES.

\section{Materials and Methods}

\subsection{General Considerations}

All manipulations were performed under either a dry nitrogen atmosphere using standard Schlenk techniques or a vacuum atmosphere in a KK-011AS glove box. THF and toluene were purchased from Samchun Pure Chemical Company, Ltd. (Seoul, Korea), and dried over sodium/benzophenone before use. Glassware, syringes, magnetic stirring bars, and needles were dried overnight in a convection oven. Decaborane was purchased from Katchem (Kralupy nad Vltavou, Czech Republic) and used after sublimation. Bis(2-methoxyethyl)amine, morpholine, cyanuric chloride, 2-butyn-1,4-diol, t-BuOK, triethylamine, prop-2-yn-1-ol, but-3-yn-1-ol, pent-4-yn-1-ol, and N,N-dimethylaniline were purchased from Sigma-Aldrich Chemicals (Merck KGaA, Darmstadt, Germany). IR spectra of the samples were recorded on an Agilent Cary 600 Series Fourier transform (FT)-IR spectrometer (Victoria, Australia) using $\mathrm{KBr}$ disks. ${ }^{1} \mathrm{H}$ and ${ }^{13} \mathrm{C}$ NMR spectra were recorded on a JEOL-JNM-AL300 spectrometer at 300.1 and $75.4 \mathrm{MHz}$, respectively. ${ }^{11} \mathrm{~B} \mathrm{NMR}$ spectra were recorded on a Bruker Ascend 400 spectrometer (Billerica, MA, USA) (operating at $128.4 \mathrm{MHz}$ ) at the Korea Basic Science Institute (KBSI) Ochang Center. All ${ }^{11} \mathrm{~B}$ chemical shifts were referenced to $\mathrm{BF}_{3} \cdot \mathrm{O}\left(\mathrm{C}_{2} \mathrm{H}_{5}\right)_{2}(0.0 \mathrm{ppm})$, where a negative sign indicated an upfield shift. All ${ }^{1} \mathrm{H}$ and ${ }^{13} \mathrm{C}$ chemical shifts were measured relative to internal residual peaks arising from the lock solvent $\left(99.5 \% \mathrm{CDCl}_{3}\right)$ and then referenced to $\mathrm{Me}_{4} \mathrm{Si}(0.00 \mathrm{ppm})$. All melting points were uncorrected. 


\subsection{Crystal Structure Determination}

Crystals of 5 and $\mathbf{6}$ were obtained from their $\mathrm{CH}_{2} \mathrm{Cl}_{2}$ solutions, sealed in glass capillaries under argon, and mounted on the diffractometer. The preliminary examination and data collection were performed using a Bruker SMART CCD detector system single-crystal X-ray diffractometer equipped with a sealed-tube $\mathrm{X}$-ray source $(50 \mathrm{kV} \times 30 \mathrm{~mA})$ using graphite monochromated Mo K $\alpha$ radiation $(\lambda=0.71073 \AA)$. The preliminary unit cell constants were determined using a set of 45 narrow-frame $\left(0.3^{\circ}\right.$ in $\left.\omega\right)$ scans. The double pass method of scanning was used to exclude noise. The collected frames were integrated using an orientation matrix determined from the narrow-frame scans. The SMART software package (version 5.0, Madison, WI, USA) was used for data collection and SAINT (version 6.0, Madison, WI, USA) was used for frame integration [34]. The final cell constants were determined through global refinement of the $x y z$ centroids of the reflections harvested from the entire dataset. Structure solution and refinement were carried out using the SHELXTL-PLUS software package (version 4.1, Madison, WI, USA) [35].

\subsection{Cell Viability Assay (MTT Assay)}

The boron compounds were dissolved in DMSO, and the resulting solution was diluted with Dulbecco's modified Eagle's medium (DMEM) (10\% FCS), or BPA was directly dissolved in the same medium. In a 96-well culture plate (Falcon 3072), B16 melanoma and HeLa cervical carcinoma cancer cells $\left(1 \times 10^{3}\right.$ cells/well $)$ were cultured in five wells with the medium containing boron compounds at various concentrations, and then incubated for $72 \mathrm{~h}$ at $37^{\circ} \mathrm{C}$ in a $\mathrm{CO}_{2}$ incubator. DMSO is nontoxic at concentrations less than $0.5 \%$ and control experiments confirmed the nontoxicity of DMSO at the concentrations used in the present experiments. After incubation, the medium was removed, the cells were washed three times with phosphate-buffered saline [PBS (-)], and the CellTiter $96{ }^{\circledR}$ AQueous Non-Radioactive Cell Proliferation Assay (MTT) was used for counting cells on a microplate reader. The results are presented in Table 3 as the agent concentration that resulted in a cell culture with $50 \%$ of the number of cells of the corresponding untreated group $\left(\mathrm{IC}_{50}\right)$.

\subsection{In Vitro Boron Incorporation into B16 Melanoma Cells}

B16 melanoma cells were cultured in Falcon 3025 dishes $(150 \mathrm{~mm})$. When the cell population increased to fill the dish $\left(3.6 \times 10^{7}\right.$ cells $/$ dish $)$, the boron compounds and BPA $(10 \mu \mathrm{M})$ were added to the dishes. The cells were incubated for $3 \mathrm{~h}$ at $37^{\circ} \mathrm{C}$ in medium (DMEM, 10\% FBS; $20 \mathrm{~mL}$ ). The cells were washed three times with $\mathrm{Ca} / \mathrm{Mg}$-free PBS $(-)$, collected with a rubber policeman, digested with a mixture of $60 \% \mathrm{HClO}_{4}-30 \% \mathrm{H}_{2} \mathrm{O}_{2}$ (1:2) solution $(2 \mathrm{~mL})$, and finally decomposed for $1 \mathrm{~h}$ at $75^{\circ} \mathrm{C}$. After filtration through a membrane filter (Millipore, $0.22 \mathrm{~mm}$ ), the boron concentration was determined using an ICP-AES instrument [ICPS-1000-III, Shimadzu (Kyoto, Japan)]. Each experiment was performed in triplicate.

\subsection{Synthesis of 4,4'-[(6-prop-2-ynylmethoxy)-1,3,5-triazine-2,4-diyl]dimorpholine (1)}

General procedure: Prop-2-yn-1-ol $(6 \mathrm{mmol})$ and excess t-BuOK as the base were added to a stirred solution of (1,3,5-triazine-2,4-diyl)dimorpholine $(5 \mathrm{mmol})$ in THF $(30 \mathrm{~mL})$ at $0{ }^{\circ} \mathrm{C}$. The resulting mixture was stirred at room temperature for $1 \mathrm{~h}$ and then at $70^{\circ} \mathrm{C}$ for an additional $6 \mathrm{~h}$. The progress of the reaction was monitored by thin layer chromatography (TLC). After completion of the reaction, the mixture was cooled to room temperature and quenched with distilled water $(50 \mathrm{~mL} \times 3)$. The mixture was subsequently extracted with ethyl acetate $(50 \mathrm{~mL} \times 3)$. The organic layer was washed with distilled water $(30 \mathrm{~mL} \times 3)$, dried with anhydrous $\mathrm{MgSO}_{4}$, filtered, and then concentrated in vacuo. The residue was purified by flash column chromatography (ethyl acetate:n-hexane $=1: 1$ ) to obtain 1 as a white powder. Yield: $1.3 \mathrm{~g}(85 \%)$. m.p. $125-126^{\circ} \mathrm{C}$. IR $\left(\mathrm{KBr}\right.$ pellet, $\left.\mathrm{cm}^{-1}\right) \vee(\mathrm{C}-\mathrm{H}) 2983$, 2980, v(C=N) 1583. ${ }^{1} \mathrm{H} \mathrm{NMR}\left(\mathrm{CDCl}_{3}, \mathrm{ppm}\right) \delta 2.42(\mathrm{t}, J=3.0 \mathrm{~Hz}, 1 \mathrm{H}), 3.69(\mathrm{t}, J=5.0 \mathrm{~Hz}, 8 \mathrm{H}), 3.78(\mathrm{t}, J=$ 
$5.0 \mathrm{~Hz}, 8 \mathrm{H}), 5.17(\mathrm{~d}, J=2.5 \mathrm{~Hz}, 2 \mathrm{H}) ;{ }^{13} \mathrm{C} \mathrm{NMR}\left(\mathrm{CDCl}_{3}, \mathrm{ppm}\right) \delta 43.9\left(\mathrm{NCH}_{2}\right.$ in morpholine), $54.1\left(\mathrm{OCH}_{2}\right)$, $66.8\left(\mathrm{OCH}_{2}\right.$ in morpholine), 74.5 (terminal $\left.\mathrm{CH}\right), 78.6$ (internal $\mathrm{C}$ ), 166.0, 170.0 (triazine ring).

3.6. Synthesis of 4,4'-[(6-but-2-ynylmethoxy)-1,3,5-triazine-2,4-diyl]dimorpholine (2)

Pale yellow powder. Yield: $1.4 \mathrm{~g}(84 \%)$. m.p. $119-120^{\circ} \mathrm{C}$. IR (KBr pellet, $\left.\mathrm{cm}^{-1}\right) \vee(\mathrm{C}-\mathrm{H}) 2985,2975$, $v(\mathrm{C}=\mathrm{N}) 1580 .{ }^{1} \mathrm{H}$ NMR $\left(\mathrm{CDCl}_{3}, \mathrm{ppm}\right) \delta 2.00(\mathrm{t}, J=2.5 \mathrm{~Hz}, 1 \mathrm{H}), 2.66(\mathrm{~m}, 2 \mathrm{H}), 3.69(\mathrm{t}, J=5.0 \mathrm{~Hz}, 8 \mathrm{H})$, $3.77(\mathrm{t}, J=5.0 \mathrm{~Hz}, 8 \mathrm{H}), 4.38(\mathrm{t}, J=7.5 \mathrm{~Hz}, 2 \mathrm{H}) ;{ }^{13} \mathrm{C} \mathrm{NMR}\left(\mathrm{CDCl}_{3}, \mathrm{ppm}\right) \delta 19.2\left(\mathrm{CH}_{2}\right), 43.9\left(\mathrm{NCH}_{2}\right.$ in morpholine), $64.3\left(\mathrm{OCH}_{2}\right), 66.8\left(\mathrm{OCH}_{2}\right.$ in morpholine), 70.0 (terminal $\left.\mathrm{CH}\right), 80.3$ (internal $\left.\mathrm{C}\right), 166.1$, 170.3 (triazine ring).

\subsection{Synthesis of 4,4'-[(6-pent-2-ynylmethoxy)-1,3,5-triazine-2,4-diyl]dimorpholine (3)}

Pale yellow powder. Yield: $1.35 \mathrm{~g}(81 \%)$. m.p. $112-114{ }^{\circ} \mathrm{C}$. IR $\left(\mathrm{KBr}\right.$ pellet, $\left.\mathrm{cm}^{-1}\right) \vee(\mathrm{C}-\mathrm{H}) 2984$, 2980, $v(\mathrm{C}=\mathrm{N})$ 1581. ${ }^{1} \mathrm{H}$ NMR $\left(\mathrm{CDCl}_{3}, \mathrm{ppm}\right) \delta 1.94(\mathrm{t}, J=2.5 \mathrm{~Hz}, 1 \mathrm{H}), 1.97(\mathrm{~m}, 2 \mathrm{H}), 2.35(\mathrm{~m}, 2 \mathrm{H})$, $3.69(\mathrm{t}, J=5.0 \mathrm{~Hz}, 8 \mathrm{H}), 3.77(\mathrm{t}, J=5.0 \mathrm{~Hz}, 8 \mathrm{H}), 4.36(\mathrm{t}, J=7.5 \mathrm{~Hz}, 2 \mathrm{H}) ;{ }^{13} \mathrm{C} \mathrm{NMR}\left(\mathrm{CDCl}_{3}, \mathrm{ppm}\right) \delta 14.4$, $27.9\left(\mathrm{CH}_{2}\right), 43.8\left(\mathrm{NCH}_{2}\right.$ in morpholine), $65.2\left(\mathrm{OCH}_{2}\right), 66.9\left(\mathrm{OCH}_{2}\right.$ in morpholine), 68.8 (terminal $\left.\mathrm{CH}\right)$, 83.7 (internal C), 166.1, 170.9 (triazine ring).

\subsection{Synthesis of 1,4-bis(4,6-dimorpholino-1,3,5-triazin-2yloxy)but-2-yne (4)}

Pale yellow powder. Yield: $0.8 \mathrm{~g}(27 \%)$. m.p. $153-156{ }^{\circ} \mathrm{C}$. IR $\left(\mathrm{KBr}\right.$ pellet, $\left.\mathrm{cm}^{-1}\right) \vee(\mathrm{C}-\mathrm{H}) 2990$, 2980, v(C=N) 1578. ${ }^{1} \mathrm{H}$ NMR $\left(\mathrm{CDCl}_{3}, \mathrm{ppm}\right) \delta 3.69(\mathrm{t}, J=5.0 \mathrm{~Hz}, 16 \mathrm{H}), 3.78(\mathrm{t}, J=5.0 \mathrm{~Hz}, 16 \mathrm{H}), 4.94(\mathrm{t}$, $J=2.0 \mathrm{~Hz}, 4 \mathrm{H}) ;{ }^{13} \mathrm{C} \mathrm{NMR}\left(\mathrm{CDCl}_{3}, \mathrm{ppm}\right) \delta 43.9\left(\mathrm{NCH}_{2}\right.$ in morpholine), $54.3\left(\mathrm{OCH}_{2}\right), 66.8\left(\mathrm{OCH}_{2}\right.$ in morpholin), 84.8 (CC), 166.0, 169.9 (triazine ring).

\subsection{Synthesis of $N^{2}, N^{2}, N^{4}, N^{4}$-tetrakis(2-methoxyethyl)-6-(propynyloxy)-1,3,5-triazine-2,4-diamine (9)}

Pale yellow powder. Yield: $1.3 \mathrm{~g}(67 \%)$. m.p. $112-115^{\circ} \mathrm{C}$. IR $\left(\mathrm{KBr}\right.$ pellet, $\left.\mathrm{cm}^{-1}\right) \vee(\mathrm{C}-\mathrm{H}) 2992$, 2984, $v(\mathrm{C}=\mathrm{N}) 1585 .{ }^{1} \mathrm{H}$ NMR $\left(\mathrm{CDCl}_{3}, \mathrm{ppm}\right) \delta 3.26(\mathrm{~s}, 6 \mathrm{H}), 3.50(\mathrm{t}, J=5.0 \mathrm{~Hz}, 4 \mathrm{H}), 3.77(\mathrm{t}, J=5.0 \mathrm{~Hz}$, $4 \mathrm{H}), 5.00(\mathrm{~s}, 2 \mathrm{H}) .{ }^{13} \mathrm{C} \mathrm{NMR}\left(\mathrm{CDCl}_{3}, \mathrm{ppm}\right) \delta 48.3\left(\mathrm{NCH}_{2}\right), 59.2\left(\mathrm{OCH}_{2}\right), 62.9\left(\mathrm{CH}_{3} \mathrm{O}\right), 67.5\left(\mathrm{CH}_{3} \mathrm{OCH}_{2}\right)$, 70.4 (terminal $\mathrm{CH}$ ), 161.7, 175.6 (triazine ring).

\subsection{Synthesis of $N^{2}, N^{2}, N^{4}, N^{4}$-tetrakis(2-methoxyethyl)-6-(butynyloxy)-1,3,5-triazine-2,4-diamine (10)}

Pale yellow oil. Yield: $1.1 \mathrm{~g}(52 \%)$. IR (KBr pellet, $\left.\mathrm{cm}^{-1}\right) \vee(\mathrm{C}-\mathrm{H}) 2987,2981, v(\mathrm{C}=\mathrm{N})$ 1579. ${ }^{1} \mathrm{H}$ NMR $\left(\mathrm{CDCl}_{3}, \mathrm{ppm}\right) \delta 2.03(\mathrm{t}, J=6.5 \mathrm{~Hz}, 1 \mathrm{H}), 2.65(\mathrm{~m}, 2 \mathrm{H}), 3.67(\mathrm{~s}, 12 \mathrm{H}), 3.55(\mathrm{t}, J=5.0 \mathrm{~Hz}, 8 \mathrm{H}), 3.76(\mathrm{t}, J=$ $5.0 \mathrm{~Hz}, 8 \mathrm{H}), 4.26(\mathrm{t}, J=7.5 \mathrm{~Hz}, 2 \mathrm{H}) .{ }^{13} \mathrm{C} \mathrm{NMR}\left(\mathrm{CDCl}_{3}, \mathrm{ppm}\right) \delta 48.0\left(\mathrm{NCH}_{2}\right), 59.5\left(\mathrm{OCH}_{2}\right), 62.1\left(\mathrm{CH}_{3} \mathrm{O}\right)$, $68.0\left(\mathrm{CH}_{3} \mathrm{OCH}_{2}\right), 70.2$ (terminal $\left.\mathrm{CH}\right), 162.4,174.8$ (triazine ring).

\subsection{Synthesis of $N^{2}, N^{2}, N^{4}, N^{4}$-tetrakis(2-methoxyethyl)-6-(pentynyloxy)-1,3,5-triazine-2,4-diamine (11)}

Pale yellow oil. Yield: $1.43 \mathrm{~g}(67 \%)$. IR (KBr pellet, $\left.\mathrm{cm}^{-1}\right) v(\mathrm{C}-\mathrm{H})$ 2996, 2990, v(C=N) 1587. ${ }^{1} \mathrm{H} \mathrm{NMR}\left(\mathrm{CDCl}_{3}, \mathrm{ppm}\right) \delta 1.79(\mathrm{t}, J=5.8 \mathrm{~Hz}, 1 \mathrm{H}), 1.88(\mathrm{~m}, 2 \mathrm{H}), 3.30(\mathrm{~s}, 6 \mathrm{H}), 3.41(\mathrm{t}, J=5.0 \mathrm{~Hz}, 4 \mathrm{H}), 3.71(\mathrm{t}$, $J=5.0 \mathrm{~Hz}, 4 \mathrm{H}), 4.01(\mathrm{t}, J=8.0 \mathrm{~Hz}, 2 \mathrm{H}) .{ }^{13} \mathrm{C} \mathrm{NMR}\left(\mathrm{CDCl}_{3}, \mathrm{ppm}\right) \delta 18.4\left(\mathrm{CCH}_{2}\right), 29.1\left(\mathrm{CH}_{2} \mathrm{CH}_{2} \mathrm{CH}_{2}\right)$, $57.6\left(\mathrm{OCH}_{2}\right), 57.8\left(\mathrm{NCH}_{2}\right), 59.1\left(\mathrm{OCH}_{3}\right), 69.7\left(\mathrm{CH}_{2} \mathrm{OCH}_{3}\right), 71.1$ (terminal $\left.\mathrm{CH}\right), 85.5(\mathrm{CCH}), 162.8$, 177.6 (triazine ring).

3.12. Synthesis of 6, 6'-[but-2-yne-1,4-diylbis(oxy)]bis $\left[N^{2}, N^{2}, N^{4}, N^{4}\right.$-tetrakis(2-methoxyethyl)1,3,5-triazine-2,4-diamine] (12)

Pale yellow oil. Yield: $0.81 \mathrm{~g}(21 \%)$. IR (KBr pellet, $\left.\mathrm{cm}^{-1}\right) \vee(\mathrm{C}-\mathrm{H}) 2996,2991,2980, v(\mathrm{C}=\mathrm{N})$ 1576. ${ }^{1} \mathrm{H} \mathrm{NMR}\left(\mathrm{CDCl}_{3}, \mathrm{ppm}\right) \delta 3.29(\mathrm{~s}, 24 \mathrm{H}), 3.53(\mathrm{t}, J=5.5 \mathrm{~Hz}, 16 \mathrm{H}), 3.71(\mathrm{t}, J=5.5 \mathrm{~Hz}, 16 \mathrm{H}), 4.86(\mathrm{~s}$, $4 \mathrm{H}) .{ }^{13} \mathrm{C} \mathrm{NMR}\left(\mathrm{CDCl}_{3}, \mathrm{ppm}\right) \delta 54.1\left(\mathrm{NCH}_{2}\right), 58.9\left(\mathrm{OCH}_{2}\right), 70.7\left(\mathrm{CH}_{3} \mathrm{O}\right), 80.4\left(\mathrm{CH}_{3} \mathrm{OCH}_{2}\right), 165.9,169.6$ (triazine ring). 


\subsection{Synthesis of 4,4'-[6-(o-carboranylmethoxy)-1,3,5-triazine-2,4-diyl]dimorpholine (5)}

General Procedure: Compound 1 ( $5 \mathrm{mmol})$ in $10 \mathrm{~mL}$ toluene was added to a stirred solution of decaborane $(0.73 \mathrm{~g}, 6 \mathrm{mmol})$ and 1.2 equiv of $N, N$-dimethylaniline in $30 \mathrm{~mL}$ dry toluene at $0{ }^{\circ} \mathrm{C}$ was added through a cannula over a period of $60 \mathrm{~min}$. The reaction mixture was maintained at $0{ }^{\circ} \mathrm{C}$ for $30 \mathrm{~min}$ and warmed slowly to room temperature. Subsequently, the reaction mixture was heated under reflux for $12 \mathrm{~h}$. After cooling, the insoluble materials were removed by filtration through a Celite. The filtrate was diluted with $\mathrm{CH}_{2} \mathrm{Cl}_{2}(50 \mathrm{~mL})$, washed with distilled water $(30 \mathrm{~mL} \times 3)$, dried with anhydrous $\mathrm{MgSO}_{4}$, filtered, and finally concentrated in vacuo. The residue was purified by flash column chromatography (ethyl acetate:n-hexane $=1: 1$ ) to give 5 as pale yellow crystals. Yield: $1.1 \mathrm{~g}$ (51\%). m.p. 157-158 ${ }^{\circ} \mathrm{C}$. HRMS: Calcd for $\left[{ }^{12} \mathrm{C}_{14}{ }^{1} \mathrm{H}_{29}{ }^{11} \mathrm{~B}_{10}{ }^{14} \mathrm{~N}_{5}{ }^{16} \mathrm{O}_{3}\right]^{+}$425.3201. Found: 425.3197. IR $\left(\mathrm{KBr}\right.$ pellet, $\left.\mathrm{cm}^{-1}\right) \vee(\mathrm{B}-\mathrm{H}) 2588, v(\mathrm{C}-\mathrm{H}) 3021,2997, v(\mathrm{C}=\mathrm{N}) 1587 .{ }^{1} \mathrm{H} \mathrm{NMR}\left(\mathrm{CDCl}_{3}, \mathrm{ppm}\right) \delta 3.55(\mathrm{t}, J=$ $6.0 \mathrm{~Hz}, 8 \mathrm{H}), 3.74(\mathrm{t}, J=6.0 \mathrm{~Hz}, 8 \mathrm{H}), 4.45$ (br s, $1 \mathrm{H}), 4.83(\mathrm{~s}, 2 \mathrm{H}) ;{ }^{13} \mathrm{C} \mathrm{NMR}\left(\mathrm{CDCl}_{3}, \mathrm{ppm}\right) \delta 47.5,48.8$ $\left(\mathrm{NCH}_{2}\right.$ in morpholine), $66.0\left(\mathrm{OCH}_{2}\right), 70.5,70.8\left(\mathrm{OCH}_{2}\right.$ in morpholin), $73.0(\mathrm{CH}$ in carborane), 165.8, 169.3 (triazine ring).

\subsection{Synthesis of 4,4'-[6-(o-carboranylethoxy)-1,3,5-triazine-2,4-diyl]dimorpholine (6)}

Pale yellow crystals. Yield: $1.1 \mathrm{~g}(49 \%)$. m.p. $137-139{ }^{\circ} \mathrm{C}$. HRMS: Calcd for $\left[{ }^{12} \mathrm{C}_{15}{ }^{1} \mathrm{H}_{31}{ }^{11} \mathrm{~B}_{10}{ }^{14} \mathrm{~N}_{5}{ }^{16} \mathrm{O}_{3}\right]^{+}$ 439.3357. Found: 439.3353. IR (KBr pellet, $\left.\mathrm{cm}^{-1}\right) v(\mathrm{~B}-\mathrm{H})$ 2596, $v(\mathrm{C}-\mathrm{H})$ 3005, 2991, v(C=N) 1576. ${ }^{1} \mathrm{H} \mathrm{NMR}\left(\mathrm{CDCl}_{3}, \mathrm{ppm}\right) \delta 2.69(\mathrm{t}, J=6.0 \mathrm{~Hz}, 2 \mathrm{H}), 3.56(\mathrm{t}, J=5.1 \mathrm{~Hz}, 8 \mathrm{H}), 3.75(\mathrm{t}, J=5.1 \mathrm{~Hz}, 8 \mathrm{H}), 3.89$ (br s, $1 \mathrm{H}), 4.34(\mathrm{t}, J=6.0 \mathrm{~Hz}, 2 \mathrm{H}) ;{ }^{13} \mathrm{C} \mathrm{NMR}\left(\mathrm{CDCl}_{3}, \mathrm{ppm}\right) \delta 36.2\left(\mathrm{CH}_{2} \mathrm{Cab}\right), 47.6,48.0\left(\mathrm{NCH}_{2}\right.$ in morpholine), $63.7\left(\mathrm{OCH}_{2}\right), 70.6,70.9\left(\mathrm{OCH}_{2}\right.$ in morpholine), 72.3 ( $\mathrm{CH}$ in carborane), 165.9, 169.5 (triazine ring).

\subsection{Synthesis of 4,4'-[6-(o-carboranylpropoxy)-1,3,5-triazine-2,4-diyl]dimorpholine (7)}

Pale yellow powder. Yield: $0.9 \mathrm{~g}(40 \%)$. m.p. $131-133{ }^{\circ} \mathrm{C}$. HRMS: Calcd for $\left[{ }^{12} \mathrm{C}_{16}{ }^{1} \mathrm{H}_{33}{ }^{11} \mathrm{~B}_{10}{ }^{14} \mathrm{~N}_{5}{ }^{16} \mathrm{O}_{3}\right]^{+}$ 453.3514. Found: 453.3518. IR (KBr pellet, $\left.\mathrm{cm}^{-1}\right) v(\mathrm{~B}-\mathrm{H})$ 2591, $v(\mathrm{C}-\mathrm{H})$ 2998, 2989, v(C=N) 1580. ${ }^{1} \mathrm{H} \mathrm{NMR}\left(\mathrm{CDCl}_{3}, \mathrm{ppm}\right) \delta 1.89(\mathrm{~m}, 2 \mathrm{H}), 2.35(\mathrm{t}, J=8.8 \mathrm{~Hz}, 2 \mathrm{H}), 3.53(\mathrm{t}, J=5.9 \mathrm{~Hz}, 8 \mathrm{H}), 3.63(\mathrm{br} \mathrm{s}, 1 \mathrm{H})$, $3.73(\mathrm{t}, J=5.9 \mathrm{~Hz}, 8 \mathrm{H}), 4.20(\mathrm{t}, J=6.0 \mathrm{~Hz}, 2 \mathrm{H}) ;{ }^{13} \mathrm{C} \mathrm{NMR}\left(\mathrm{CDCl}_{3}, \mathrm{ppm}\right) \delta 28.7\left(\mathrm{CH}_{2} \mathrm{Cab}\right), 35.0\left(\mathrm{CH}_{2} \mathrm{CH}_{2}\right)$, 47.6, $47.9\left(\mathrm{NCH}_{2}\right.$ in morpholine $), 64.7\left(\mathrm{OCH}_{2}\right), 70.6,71.0\left(\mathrm{OCH}_{2}\right.$ in morpholine $), 74.8(\mathrm{CH}$ in carborane), $165.9,170.1$ (triazine ring).

\subsection{Synthesis of 1,2-bis[(4,6-dimorpholino-1,3,5-triazin-2-yloxy)methyl]-o-carborane (8)}

Pale yellow powder. Yield: $1.4 \mathrm{~g}(40 \%)$ m.p. 154-158 ${ }^{\circ} \mathrm{C}$. HRMS: Calcd for $\left[{ }^{12} \mathrm{C}_{26}{ }^{1} \mathrm{H}_{46}{ }^{11} \mathrm{~B}_{10}{ }^{14} \mathrm{~N}_{10}{ }^{16} \mathrm{O}_{6}\right]^{+}$704.4532. Found: 704.4539. IR (KBr pellet, $\left.\mathrm{cm}^{-1}\right) v(\mathrm{~B}-\mathrm{H}) 2587, v(\mathrm{C}-\mathrm{H})$ 2988, 2980, 2889, v(C=N) 1583. ${ }^{1} \mathrm{H}$ NMR $\left(\mathrm{CDCl}_{3}, \mathrm{ppm}\right) \delta 3.28(\mathrm{~s}, 2 \mathrm{H}), 3.53(\mathrm{~m}, 16 \mathrm{H}), 3.73(\mathrm{~m}, 16 \mathrm{H}) .{ }^{13} \mathrm{C}$ NMR $\left(\mathrm{CDCl}_{3}, \mathrm{ppm}\right) \delta 47.6,47.7,48.0\left(\mathrm{NCH}_{2}\right.$ in morpholine $), 58.8\left(\mathrm{OCH}_{2}\right), 64.0$ (C in carborane), 70.5, 71.0, $71.4\left(\mathrm{OCH}_{2}\right.$ in morpholine), 165.3, 169.6 (triazine ring).

\subsection{7. (6-o-carboranylmethoxy)- $N^{2}, N^{2}, N^{4}, N^{4}$-tetrakis(2-methoxyethyl)-1,3,5-triazine-2,4-diamine (13)}

Pale yellow powder. Yield: $1.35 \mathrm{~g}$ (51\%). m.p. 128-131 ${ }^{\circ} \mathrm{C}$. HRMS: Calcd for $\left[{ }^{12} \mathrm{C}_{18}{ }^{1} \mathrm{H}_{41}{ }^{11} \mathrm{~B}_{10}{ }^{14} \mathrm{~N}_{5}{ }^{16} \mathrm{O}_{5}\right]^{+}$517.4038. Found: 517.4041. IR $\left(\mathrm{KBr}\right.$ pellet, $\left.\mathrm{cm}^{-1}\right) v(\mathrm{~B}-\mathrm{H}) 2594, v(\mathrm{C}-\mathrm{H})$ 2999, 2991, 2898, v(C=N) 1578. ${ }^{1} \mathrm{H} \mathrm{NMR}\left(\mathrm{CDCl}_{3}, \mathrm{ppm}\right) \delta 3.70(\mathrm{t}, J=5.0 \mathrm{~Hz}, 8 \mathrm{H}), 3.73(\mathrm{t}, J=5.0 \mathrm{~Hz}, 8 \mathrm{H})$, 4.01 (br s, $1 \mathrm{H}), 4.78$ (s, 2H). ${ }^{13} \mathrm{C} \mathrm{NMR}\left(\mathrm{CDCl}_{3}, \mathrm{ppm}\right) \delta 43.8\left(\mathrm{OCH}_{3}\right), 58.0\left(\mathrm{OCH}_{2}\right), 66.1\left(\mathrm{NCH}_{2}\right), 66.6$ $\left(\mathrm{CH}_{3} \mathrm{OCH}_{2}\right), 72.1$ ( $\mathrm{CH}$ in carborane), 165.6, 169.5 (triazine ring).

\subsection{8. (6-o-carboranylethoxy)- $N^{2}, N^{2}, N^{4}, N^{4}$-tetrakis(2-methoxyethyl)-1,3,5-triazine-2,4-diamine (14)}

Pale yellow oil. Yield: $1.3 \mathrm{~g}$ (49\%). HRMS: Calcd for $\left[{ }^{12} \mathrm{C}_{19}{ }^{1} \mathrm{H}_{43}{ }^{11} \mathrm{~B}_{10}{ }^{14} \mathrm{~N}_{5}{ }^{16} \mathrm{O}_{5}\right]^{+} 531.4195$. Found: 531.4200. IR (KBr pellet, $\left.\mathrm{cm}^{-1}\right)$ v(B-H) 2590, v(C-H) 2987, 2981, 2889, v(C=N) 1585. ${ }^{1} \mathrm{H} \mathrm{NMR}\left(\mathrm{CDCl}_{3}\right.$, ppm) $\delta 2.69(\mathrm{t}, J=6.6 \mathrm{~Hz}, 2 \mathrm{H}), 3.69(\mathrm{t}, J=5.1 \mathrm{~Hz}, 8 \mathrm{H}), 3.70(\mathrm{t}, J=5.1 \mathrm{~Hz}, 8 \mathrm{H}), 3.81(\mathrm{br} \mathrm{s}, 1 \mathrm{H}), 4.33(\mathrm{t}, J=$ 
$6.6 \mathrm{~Hz}, 2 \mathrm{H}) .{ }^{13} \mathrm{C} \mathrm{NMR}\left(\mathrm{CDCl}_{3}, \mathrm{ppm}\right) \delta 36.4\left(\mathrm{CH}_{2} \mathrm{Cab}\right), 43.8\left(\mathrm{OCH}_{3}\right), 60.1\left(\mathrm{OCH}_{2}\right), 63.9\left(\mathrm{NCH}_{2}\right), 66.7$ $\left(\mathrm{OCH}_{3} \mathrm{OCH}_{2}\right), 72.3$ ( $\mathrm{CH}$ in carborane), 165.8, 169.9 (triazine ring).

\subsection{9. (6-o-carboranylpropoxy)- $N^{2}, N^{2}, N^{4}, N^{4}$-tetrakis(2-methoxyethyl)-1,3,5-triazine-2,4-diamine (15)}

Pale yellow oil. Yield: $1.1 \mathrm{~g}(40 \%)$. HRMS: Calcd for $\left[{ }^{12} \mathrm{C}_{20}{ }^{1} \mathrm{H}_{45}{ }^{11} \mathrm{~B}_{10}{ }^{14} \mathrm{~N}_{5}{ }^{16} \mathrm{O}_{5}\right]^{+} 545.4351$. Found:

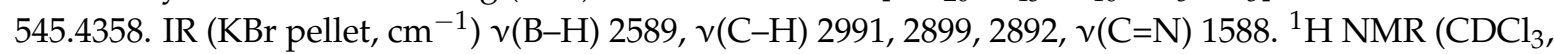
ppm) $\delta 1.94(\mathrm{~m}, 2 \mathrm{H}), 2.38(\mathrm{t}, J=8.4 \mathrm{~Hz}, 2 \mathrm{H}), 3.55(\mathrm{br} \mathrm{s}, 1 \mathrm{H}), 3.69(\mathrm{t}, J=5.0 \mathrm{~Hz}, 8 \mathrm{H}), 3.73(\mathrm{t}, J=5.0 \mathrm{~Hz}$, $8 \mathrm{H}), 4.23(\mathrm{t}, J=5.8 \mathrm{~Hz}, 2 \mathrm{H}) .{ }^{13} \mathrm{C} \mathrm{NMR}\left(\mathrm{CDCl}_{3}, \mathrm{ppm}\right) \delta 28.6\left(\mathrm{CH}_{2} \mathrm{Cab}\right), 35.1\left(\mathrm{CH}_{2} \mathrm{CH}_{2}\right), 43.7\left(\mathrm{OCH}_{3}\right)$, $61.4\left(\mathrm{OCH}_{2}\right), 65.0\left(\mathrm{NCH}_{2}\right), 66.7\left(\mathrm{CH}_{3} \mathrm{OCH}_{2}\right), 74.5(\mathrm{CH}$ in carborane), 165.8, 170.5 (triazine ring).

\subsection{6,6'-[1,2-o-carboranylbis(methylene)bis(oxy)]bis $\left[N^{2}, N^{2}, N^{4}, N^{4}\right.$-tetrakis(2-methoxyethyl)-}

\section{1,3,5-triazine-2,4-diamine] (16)}

Pale yellow oil. Yield: $0.67 \mathrm{~g}(15 \%)$. HRMS: Calcd for $\left[{ }^{12} \mathrm{C}_{34}{ }^{1} \mathrm{H}_{70}{ }^{11} \mathrm{~B}_{10}{ }^{14} \mathrm{~N}_{10}{ }^{16} \mathrm{O}_{10}\right]^{+} 888.6207$. Found: 888.6214. IR (KBr pellet, $\mathrm{cm}^{-1}$ ) $v(\mathrm{~B}-\mathrm{H}) 2590, v(\mathrm{C}-\mathrm{H}) 2988,2986,2980, v(\mathrm{C}=\mathrm{N})$ 1587. ${ }^{1} \mathrm{H}$ NMR $\left(\mathrm{CDCl}_{3}, \mathrm{ppm}\right) \delta 3.68(\mathrm{~m}, 16 \mathrm{H}), 3.70(\mathrm{~s}, 24 \mathrm{H}), 3.72(\mathrm{~m}, 16 \mathrm{H}), 5.0(\mathrm{~s}, 4 \mathrm{H}) .{ }^{13} \mathrm{C} \mathrm{NMR}\left(\mathrm{CDCl}_{3}, \mathrm{ppm}\right) \delta 30.2$ $\left(\mathrm{CH}_{2} \mathrm{Cab}\right), 43.8\left(\mathrm{OCH}_{3}\right), 61.8\left(\mathrm{OCH}_{2}\right), 64.5\left(\mathrm{NCH}_{2}\right), 68.4\left(\mathrm{CH}_{3} \mathrm{OCH}_{2}\right), 165.7$, 169.6 (triazine ring).

\section{Conclusions}

In this study, we have described the synthesis, X-ray structures, and biological activities of a series of mono- and bis(triazinyl)-o-carboranes with polar functional groups such as bis[(2-methoxyethyl)]amine and morpholine, which can easily be further substituted in a one-pot method to produce highly active biological molecules for BNCT. We have developed a general and versatile method for the preparation of triazines flanked with an $o$-carborane. The selective nucleophilic substitution performed in this study is a mild process that should have great potential for use in medicinal chemistry for the attachment of chemically sensitive targeting moieties to pharmacophores for BNCT.

Supplementary Materials: Supplementary Materials are available online. Figure S1-S26: NMR spectra of Compounds 5-8 and 13-16, and X-ray structures of Compounds 5 and 6, Tables S1-S6: Detailed information on the structural determinations and structural features of compounds $\mathbf{5}$ and $\mathbf{6}$ are provided in the Supplementary Materials.

Author Contributions: Conceptualization, J.D.L. and H.S.B.; Designed and performed biological tests, H.S.B. and H.N.; Chemical experiments, G.F.J.; Data Curation, J.D.L. and H.S.B.; Writing-Original Draft Preparation, J.D.L. and H.S.B.; Writing-Review \& Editing, J.D.L. and H.S.B.; Supervision, J.D.L.; Project Administration, J.D.L.; Funding Acquisition, J.D.L.

Funding: This research received no external funding.

Acknowledgments: This research was supported by Basic Science Research Program through the National Research Foundation of Korea (NRF) funded by the Ministry of Education (2016R1D1A1B04933311) and also this work was supported by research fund from Chosun University, 2015.

Conflicts of Interest: The authors declare no conflict of interest.

\section{Appendix A}

CCDC 1815582 and 1815583 contains the supplementary crystallographic data of $\mathbf{5}$ and $\mathbf{6}$ for this paper. These data can be obtained free of charge via www.ccdc.cam.ac.uk/conts/retrieving.html (or from the Cambridge Crystallographic Data Centre, 12, Union Road, Cambridge CB2 1EZ, UK; Fax: +44 1223 336033; or deposit@ccdc.cam.ac.uk). Additional Supporting Information may be found online in the supporting information tab for this article.

\section{References}

1. Zhu, Y.; Hosmane, N.S. Nanostructured boron compounds for cancer therapy. Pure Appl. Chem. 2018, 90, 653-663. [CrossRef] 
2. Satapathy, R.; Dash, B.P.; Mahanta, C.S.; Swain, B.R.; Jena, B.B.; Hosmane, N.S. Cylcoconjugates of polyhedral boron clusters. J. Organomet. Chem. 2015, 798, 13-23. [CrossRef]

3. Hawthorne, M.F.; Lee, M.W. A critical assessment of boron target compounds for boron neutron capture therapy. J. Neuro-Oncol. 2003, 62, 33-45. [CrossRef]

4. Hosmane, N.S. Boron and Gadolinium Neutron Capture Therapy for Cancer Treatment; World Scientific Publishing Co.: Singapore, 2012.

5. Hosmane, N.S. Boron Science: New Technologies and Applications; CRC Press: Boca Raton, FL, USA, 2011.

6. Azab, A.K.; Abu Ali, H.; Srebnik, M. Boron Neutron Capture Therapy. In Studies in Inorganic Chemistry; Abu Ali, H., Dembitsky, V.M., Srebnik, M., Eds.; Elsevier: New York, NY, USA, 2005; Chapter 5; pp. 337-366.

7. Barth, R.F.; Coderre, J.A.; Vicente, M.G.H.; Blue, T.E. Boron neutron capture therapy of cancer: Current status and future prospects. Clin. Cancer Res. 2005, 11, 3987-4002. [CrossRef] [PubMed]

8. Pisarev, M.A.; Dagrosa, M.A.; Juvenal, G.J. Boron neutron capture therapy in cancer: Past, present and future. Arq. Bras. Endocrinol. Metab. 2007, 51, 852-856. [CrossRef]

9. Barth, R.F.; Vicente, M.G.H.; Harling, O.K.; Kiger, W.S., III; Riley, K.J.; Binns, P.J.; Wagner, F.M.; Suzuki, M.; Aihara, T.; Kato, I.; et al. Current status of boron neutron capture therapy of high grade gliomas and recurrent head and neck cancer. Radiat. Oncol. 2012, 7, 146. [CrossRef] [PubMed]

10. Soloway, A.H.; Tjarks, W.; Barnum, B.A.; Rong, F.-G.; Barth, R.F.; Codogni, I.M.; Wilson, J.G. The chemistry of neutron capture therapy. Chem. Rev. 1998, 98, 1515-1562. [CrossRef] [PubMed]

11. Hawthorne, M.F. New horizons for therapy based on the boron neutron capture reaction. Mol. Med. Today 1998, 4, 174-181. [CrossRef]

12. Hawthorne, M.F. The role of chemistry in the development of boron neutron capture therapy of cancer. Angew. Chem. Int. Ed. Engl. 1993, 32, 950-984. [CrossRef]

13. Fauchere, J.-L.; Leukart, O.; Eberie, A.; Schwyzer, R. The synthesis of [4-carboranylalanine, 5-leucine]enkephalin (including an improved preparation of t-butoxycarbonyl-L-o-carboranylalanine, new derivatives of L-propargylglycine, and a note on melanotropic and opiate receptor binding characteristics. Helv. Chim. Acta 1979, 62, 1385-1395. [CrossRef]

14. Leukart, O.; Caviezel, M.; Eberie, A.; Escher, E.; Tun-Kyi, A.; Schwyer, R. L-o-carboranylalanine, a boron analogue of phenylalanine. Helv. Chim. Acta 1976, 59, 2184-2187. [CrossRef]

15. Valliant, J.F.; Guenther, K.J.; King, A.S.; Morel, P.; Schaffer, P.; Sogbein, O.O.; Stephenson, K.A. The medicinal chemistry of carboranes. Coord. Chem. Rev. 2002, 232, 173-230. [CrossRef]

16. Lee, J.-D.; Lee, C.-H.; Nakamura, H.; Ko, J.; Kang, S.O. A convenient synthesis of the novel carboranylsubstituted tetrahydroisoquinolines: Application to the biologically active agent for BNCT. Tetrahedron Lett. 2002, 43, 5483-5486. [CrossRef]

17. Lee, C.-H.; Jin, G.F.; Yoon, J.H.; Kim, S.H.; Lee, J.-D.; Nakamura, H.; Kang, S.O. Triazinyl architecture on bifunctional carboranyl templates for the production of potential neutron capture therapy agents: Synthesis and characterization of 1,3,5-triazinylcarborane derivatives. Synthesis 2008, 1193-1200. [CrossRef]

18. Lee, C.-H.; Jin, G.F.; Yoon, J.H.; Jung, Y.U.; Lee, J.-D.; Cho, S.; Nakamura, H.; Kang, S.O. Synthesis and characterization of polar functional group substituted mono- and bis-(o-carboranyl)-1,3,5-triazine derivatives. Tetrahedron Lett. 2008, 49, 159-164. [CrossRef]

19. Lee, C.-H.; Lim, H.-G.; Lee, J.-D.; Lee, Y.-J.; Ko, J.; Nakamura, H.; Kang, S.O. o-Carboranyl derivatives of 1,3,5-s-triazines: Structures, properties and in vitro activities. Appl. Organometal. Chem. 2003, 17, 539-548. [CrossRef]

20. Lee, C.-H.; Oh, J.M.; Lee, J.-D.; Nakamura, H.; Ko, J.; Kang, S.O. Synthesis of THIQ derivatives as potential boron neutron capture therapy agents: $N$-functionalized o-carboranylmethyl benzopiperidines. Synlett 2006, 275-278. [CrossRef]

21. Lee, C.-H.; Yang, I.D.; Lee, J.-D.; Nakamura, H.; Ko, J.; Kang, S.O. Synthesis of N-functionalized 3,4-o-carboranylenepiperidines as potential boron neutron capture therapy agents. Synlett 2004, 1799-1801. [CrossRef]

22. Fujii, S.; Goto, T.; Ohta, K.; Hashimoto, Y.; Suzuki, T.; Ohta, S.; Endo, Y. Potent androgen antagonists based on carborane as a hydrophobic core structure. J. Med. Chem. 2005, 48, 4654-4662. [CrossRef] [PubMed]

23. Reynolds, R.C.; Campbell, S.R.; Fairchild, R.G.; Kisliuk, R.L.; Micca, P.L.; Queener, S.F.; Riordan, J.M.; Sedwick, W.D.; Waud, W.R.; Leung, A.K.W.; et al. Novel boron-containing, nonclassical antifolates: Synthesis and preliminary biological and structural evaluation. J. Med. Chem. 2007, 50, 3283-3289. [CrossRef] [PubMed] 
24. Azev, Y.; Slepukhina, I.; Gabel, D. Synthesis of boron-containing heterocyclic compounds. Appl. Radiat. Isotope 2004, 61, 1107-1110. [CrossRef] [PubMed]

25. Ronchi, S.; Prosperi, D.; Compostella, F.; Panza, L. Synthesis of novel carborane-hybrids based on a triazine scaffold for boron neutron capture therapy. Synlett 2004, 1007-1010. [CrossRef]

26. Lee, J.-D.; Cho, S.J.; Kim, S.H.; Chai, G.Y.; Lee, C.-H. New types of o-carboranyl heterocyclic compounds: Synthesis and characterization of morpholino and di(methoxyethyl)amino substituted 1,3,5-triazine derivatives. Bull. Korean Chem. Soc. 2012, 33, 3136-3138. [CrossRef]

27. Zeng, T.; Dong, C.M.; Shu, X.G.; Li, J.S.; Huang, P.M. 2-Chloro-4,6-dimorpholino-1,3,5-triazine. Acta Crystallogr. Sect. E 2005, 61, o2211-o2212. [CrossRef]

28. Dong, J.Y.; Huang, P.M. 4,6-Dimorpholino-N-(2,4,4-trimethylpentan-2-yl)-1,3,5-triazin-2-amine. Acta Crystallogr. Sect. E 2007, 63, o4028. [CrossRef]

29. Davidson, M.G.; Hibbert, T.G.; Howard, J.A.K.; Mackinnon, A.; Wade, K. Definitive crystal structures of ortho-, meta- and para-carboranes: Supramolecular structures directed solely by C-H.O hydrogen bonding to hmpa (hmpa = hexamethylphosphoramide). Chem. Commun. 1996, 2285-2286. [CrossRef]

30. Lee, J.-D.; Lee, Y.-J.; Jeong, H.-J.; Lee, J.S.; Lee, C.-H.; Ko, J.; Kang, S.O. Practical synthesis of amonoethyl-o-carboranes. Organometallics 2003, 22, 445-449. [CrossRef]

31. Welch, A.J.; Venkatasubramanian, U.; Rosair, G.M.; Ellis, D.; Donohoe, D.J. Crystal engineering with heteroboranes. I. 1-Carboxy-1,2-dicarba-closo-dodecaborane(11). Acta Crystallogr. Sect. C 2001, 57, 1295-1296. [CrossRef]

32. Wu, Y.; Carroll, P.J.; Kang, S.O.; Quintana, W. Synthesis, characterization, and reactivity of isocyanato dicarbaboranes obtained from o-carborane. Inorg. Chem. 1997, 36, 4753-4761. [CrossRef] [PubMed]

33. Nie, Y.; Wang, Y.; Miao, J.; Li, Y.; Zhang, Z. Synthesis and characterization of carboranyl Schiff base compounds from 1-amino-o-carborane. J. Organomet. Chem. 2015, 798, 182-188. [CrossRef]

34. SMART and SAINT; Bruker Analytical X-ray Division: Madison, WI, USA, 2002.

35. Sheldrick, G.M. SHELXTL-PLUS Software Package; Bruker Analytical X-ray Division: Madison, WI, USA, 2002.

Sample Availability: Samples of the compounds 5-8 and 13-16 are available from the authors.

(C) 2018 by the authors. Licensee MDPI, Basel, Switzerland. This article is an open access article distributed under the terms and conditions of the Creative Commons Attribution (CC BY) license (http://creativecommons.org/licenses/by/4.0/). 